\title{
Interaksi Sosial Pedagang Sayur di Pasar Induk Namlea Kabupaten Buru
}

\author{
M. Rusdi ${ }^{1}$, Siti Hajar Loilatu ${ }^{2}$, Ismail ${ }^{3}$, Radiatan Mardiah ${ }^{4}$, Astriani A. Papuangan ${ }^{5}$ \\ ${ }^{1}$ Pendidikan Sosiologi, Universitas Iqra Buru \\ ${ }^{2}$ Pendidikan Matematika, Universitas Iqra Buru \\ ${ }^{3}$ Pendidikan Sosiologi, Sekolah Tinggi DDI Pangkep \\ ${ }^{3}$ Manajemen Pendidikan Islam, Sekolah Tinggi DDI Pangkep \\ ${ }^{5}$ Pendidikan Sosiologi, Institus Agama Islam As-Siddiq Kie Raha Maluku Utara \\ Email: ${ }^{1}$ rusdigallarang92@gmail.com 2 azhaloilatu@gmail.com ${ }^{3}$ ismailsosiologi2@ gmail.com \\ radhiatanmardhiya@gmail.com ${ }^{5}$ astriyanipapuangan@gmail.com
}

\begin{abstract}
This study aims to describe the form of social interaction and the factors that influence the interaction carried out by vegetable sellers at the Namlea supermarket, Buru Regency. The next purpose of this research is to reveal and explain the positive values contained in social interaction. This is a descriptive qualitative research. Informants are determined by purposive sampling. Data collection was carried out in some stages such as; observation, interviews, and documentation. And data analysis is done by; data reduction, data presentation and data verification. The results of the study explain that the form of social interaction carried out by vegetable sellers at the Namlea supermarket is a form of interaction that occurs individuals to individuals, group to group and individuals to groups. This form of interaction occurs at certain times, which is divided into associative and dissociative social interactions. While the factors for the occurrence of forms of social interaction, namely; cooperation, assimilation, accommodation, competition and conflict.
\end{abstract}

Keywords: Social Interaction, Vegetable Sellers

\begin{abstract}
Abstrak
Penelitian ini bertujuan untuk mendeskriptifkan bentuk interaksi sosial dan faktor yang mempengaruhi terjadinya interaksi yang dilakukan oleh para pedagang sayur di pasar induk Namlea, Kabupaten Buru. Tujuan selanjutnya ialah untuk mengungkap serta menjelaskan nilai-nilai positif yang terkandung dari interaksi sosial. Penelitian ini adalah jenis penelitian kualitatif yang bersifat deskriptif. Informan di tentukan dengan cara purposive sampling. Pengumpulan data dilakukan dengan tahapan observasi, wawancara, dan dokumentasi. Serta analisis data dilakukan dengan cara; reduksi data, penyajian data dan verifikasi data. Hasil penelitian menjelaskan bahwa, bentuk interaksi sosial yang dilakukan oleh pedagang sayur di pasar Namlea, merupakan bentuk interaksi yang terjadi secara individu dengan individu, kelompok dengan kelompok maupun individu dengan kelompok. Bentuk interaksi ini terjadi di waktu-waktu tertentu, yang terbagi ke dalam bentuk interaksi sosial asosiatif dan disosiatif. Sedangkan faktor terjadinya bentuk interaksi sosial, yaitu; kerja sama, asimilasi, akomodasi, persaingan, dan konflik.
\end{abstract}

Kata Kunci: Interaksi Sosial, Pedagang Sayur

\section{PENDAHULUAN}

Manusia adalah mahluk sosial dan selalu berhubungan satu sama lain melalui proses interaksi. Dalam kehidupannya manusia akan selalu melakukan hubungan dengan manusia lain, dan menyusaikan diri dengan lingkungan tempat tinggalnya. Proses interaksi akan berlangsung apabila dalam suatu hubungan terdapat dua individu atau lebih melakukan kontak, dimana setiap kelakuan individu akan mempengaruhi, mengubah dan memperbaiki kelakuan individu lain atau sebaliknya. Sehingga dari interaksi tersebut dapat menimbulkan hubungan kerjasama yang baik diantara para pelaku interaksi sosial (Triwik Alfia Ningrum,2013:498). Setiap individu tentunya akan selalu melakukan hubungan melalui interaksi dengan orang lain dalam menjalani kehidupan sehari-hari.

Pasar adalah salah satu wadah bertemunya antara penjual dan pembeli, proses pertukaran uang dan barang sehingga terjadi pemindahan hak milik. Pertemuan antara penjual dan pembeli akan memberikan peluang terjadinya interaksi. Kegiatan transaksi jual beli antara individu yang satu (Penjual) dengan individu yang lain (pembeli) akan menimbulkan hubungan sosial yang dipengaruhi oleh konteks sosial budaya yang sedang berkembang di masyarakat.

Pasar adalah institusi sosial yang didalamnya terdapat aturan norma, sanksi yang 
dibentuk melalui proses interaksi. Hal ini menegaskan bahwa pasar tidak hanya menjadi ruang ekonomi, tetapi juga terdapat ruang sosial. Di ruang inilah modal sosial terus diaktifkan, karena memberikan potensi untuk mengeratkan hubungan sosial dan memungkinkan langgengnya transaksi ekonomi. Dengan hadirnya pusat perbelanjaan seperti di pasar Namlea Kabupaten Buru yang diisi oleh para pedagang, maka akan terjadi pertemuan antara dua orang atau lebih dan interaksi sosial akan terjadi. Pertemuan diawali dengan saling menegur, berjabat tangan dan saling berbicara. Aktivitas tersebut merupakan bentuk dari interaksi sosial yang akan memberikan pengaruh dalam berperilaku dan bersikap. Mereka akan saling mempengaruhi, dan hasil dari interaksi tersebut akan memberikan dampak positif dan negatif.

Proses persaingan terus terjadi antar pedagang dan berbagai cara dilakukan untuk menarik perhatian pengunjung. Komunikasi dilakukan secara langsung dan terjadi bukan hanya pada proses transaksi saja, tetapi ada bincang-bincang antara penjual dengan pembeli sehingga pasar Namlea menjadi media sosial dan memberikan hubungan personal antar penjual dan pembeli, pembeli dengan pembeli maupun pedagang dengan pedagang. Intensitas pertemuan yang relatif tinggi memberikan kedekatan sosial. Misalnya pedagang yang memiliki pelanggang setia, akan memberikan harga lebih murah dari pembeli lainnya. Kedekatan tersebut akan berlanjut diluar aktifitas ekonomi. Misalnya pedagang atau pembeli mengadakan pesta, maka mereka akan saling mengundang seolah sudah menjadi kerabat dekat. Hubungan seperti ini jika terus berlangsung akan memberikan dampak positiv untuk menciptakan kedekatan sosial.

Interaksi antar pedagang di pasar Namlea terlihat ketika sunyi pengunjung. Meski sering terjadi persaingan dan perselisihan dalam perebutan pengunjung, tetapi hubungan baik tetap harus dibina agar tercipta suasana tentram tanpa perselisihan. Sehingga masalah yang akan diteliti adalah bagaimana bentuk interaksi sosial pedagang sayur dan faktor apa yang mempengaruhi terjadinya bentuk interaksi sosial di pasar Namlea Kabupaten Buru.
Dari permasalahan tersebut, maka penelitian ini bertujuan untuk mendeskriptifkan bentuk interaksi sosial dan faktor yang mempengaruhi terjadinya bentuk interaksi di pasar Namlea. Tujuan selanjutnya dari penelitian ini adalah untuk mengungkap serta menjelaskan nilai-nilai positif yang terkandung dari interaksi sosial yang terjadi di pasar Namlea sebagai satu-satunnya pasar yang ada di pusat kota Kabupaten Buru.

Selanjutnya, pada penelitian ini state of the art, diambil contoh penelitian terdahulu sebagai panduan diantaranya adalah jurnal Diskursus Islam Nasional dan Jurnal Komunitas Nasional. Dapat dilihat pada gambar yang telah dilampirkan.

Tabel 2.1 State Of The Art

\begin{tabular}{|l|l|}
\hline Judul Penelitian & Interaksi Sosial Komunitas Samin Dengan Masyarakat Sekitar \\
\hline Peneliti & Indah Puji Lestari \\
\hline tahun & 2013 \\
\hline Variabel yang terkait & Interaksi Sosial Masyarakat \\
\hline Hasil/ Temuan & $\begin{array}{l}\text { Hasil penelitian ini menunjukkan bahwa bentuk-bentuk interaksi } \\
\text { sosial antara komunitas Samin dengan masyarakat sekitar berupa } \\
\text { kerja sama, akomodasi dan asimilasi. Sedangkan konflik atau } \\
\text { pertentangan dalam interaksi sosial antara komunitas Samin dengan } \\
\text { mayarakat sekitar desa Klopoduwur tidak tampak jelas. Interaksi } \\
\text { sosial antara komunitas Samin dengan masyarakat sekitar } \\
\text { dipengaruhi oleh berbagai faktor, yakni situasi sosial, kekuasaan } \\
\text { norma kelompok, tujuan pribadi, kedudukan dan kondisi individu } \\
\text { serta penafsiran situasi. Kendala-kendala yang dihadapi dalam } \\
\text { interaksi sosial antara komunitas Samin dengan masyarakat sekitar } \\
\text { adalah perbedaan bahasa yang sulit dipahami oleh masyarakat } \\
\text { sekitar,dan adanya perbedaan nilai antara kedua kelompok sosial } \\
\text { tersebut. }\end{array}$ \\
\hline Persamaan & $\begin{array}{l}\text { Penelitian ini sama-sama meneliti tentang bentuk-bentuk interaksi } \\
\text { sosial. }\end{array}$ \\
\hline Perbedaan & $\begin{array}{l}\text { Penelitian yang dilakukan oleh Indah Puji Lestari adalah bentuk } \\
\text { interaksi sosial yang berlokasi di Desa Klopoduwur, Kecamatan } \\
\text { Banjarejo, Kabupaten Blora. Sedangkan penelitian ini meneliti } \\
\text { tentang bentuk interaksi sosial yang berlokasi di Desa Namlea, } \\
\text { Kabupaten Buru. }\end{array}$ \\
\hline
\end{tabular}

Berikut merupakan tabel State Of the art kedua yang terlihat jelas perbedaan dalam metode penelitiaannya.

Tabel 2.2 State Of The Art

\begin{tabular}{|l|l|}
\hline Judul Penelitian & Interaksi Sosial Dalam Masyarakat Multietnis \\
\hline Peneliti & Asrul Muslim \\
\hline tahun & 2013 \\
\hline Variabel yang terkait & Interaksi Sosial \\
\hline Hasil/ Temuan & $\begin{array}{l}\text { Bentuk interaksi manusia dengan manusia yang lain dapat dapat } \\
\text { dilihat dari bentuk asosiatif maupun disosiatif. Beberapa } \\
\text { permasalahan yang dapat menghasilkan bentuk interaksi sosial yang } \\
\text { sifatnya asosiatif adalah etnosentrisme, misunderstanding in value, } \\
\text { streotip dan prasangka. }\end{array}$ \\
\hline Persamaan & Penelitian ini sama-sama meneliti tentang bentuk interaksi sosial \\
\hline Perbedaan & $\begin{array}{l}\text { Penelitian yang dilakukan oleh Asrul Muslim adalah interaksi dalam } \\
\text { bentuk multietnis. Sedangkan penelitian ini meneliti tentang bentuk } \\
\text { interaksi sosial pedagang sayur dan faktor yang mempengaruhi } \\
\text { terjadinya bentuk interaksi sosial di pasar Namlea Kabupaten Buru. }\end{array}$ \\
\hline
\end{tabular}

\section{METODE}

Jenis penelitian ini adalah deskriptif kualitatif yaitu peneliti memberikan gambaran 
secara jelas dan sistematis terkait dengan objek yang diteliti. Penelitian ini didasari dengan maksud untuk menggambarkan secara deskriptif mengenai bentuk interaksi sosial, beserta faktor penghambat dan pendukung bentuk interaksi sosial pedagang sayur di pasar induk Namlea Kabupaten Buru. Hal tersebut yang menjadi fokus untuk dikaji dan dianalisis secara deskriptif kualitatif dalam penelitian ini. Penelitian ini dilakukan di Pasar Induk Namlea, Desa Namlea, Kabupaten Buru Provinsi Maluku.

Informan ditentukan secara Purposive Sampling dimana pemilihan informan dipilih berdasarkan ketentuan bahwa informan tersebut adalah yang melakukan, mengalami, mengetahui dan memahami persis masalah yang diteliti. Informanya adalah masyarakat lokal yang sudah lama berdagang dan berbelanja di pasar Namlea, dengan kriteria sampel benarbenar sesuai dengan penelitian yang akan dilakukan. Informan yang Pertama, dalam penelitian ini adalah masyarakat lokal yang mempunyai pengaruh dan berkompeten dalam wilayah tersebut seperti Tokoh Masyarakat, Kepala Desa, Kepala Kecamatan. Dan informan Kedua, adalah pedagang sayur dan masyarakat pengunjung yang sudah sering berbelanja di Pasar Namlea.

Teknik pengumpulan data dilakukan dengan cara; Pertama Observasi, data yang didapatkan melalui observasi meliputi bentuk interaksi sosial pedagang sayur dan faktor yang mempengaruhi terjadinya bentuk interaksi sosial. Kedua wawancara, data yang didapatkan melalui proses wawancara adalah informasi tentang bentuk interaksi sosial serta faktor yang mempengaruhi sehingga terjalin interaksi antara pedagang dan pembeli. Teknik wawancara akan dibantu dengan teknik rekam dan catat untuk memperoleh data primer dari informan dan didukung oleh data sekunder yang diperoleh dari hasil observasi, catatan lapangan, pengkajian bahan pustaka berupa buku-buku, jurnal, artikel, pemberitaan media cetak atau internet, maupun foto-foto yang relevan dengan kajian penelitian. Ketiga Dokumentasi, Adapun data yang didapatkan melalui dokumentasi ini adalah data-data tentang tempat penelitian.
Analisis data ditempuh dengan langkahlangkah, seperti: reduksi data, penyajian data dan verifikasi data. penarikan kesimpulan setelah penyajian data. Verifikasi ini memungkinkan selama penelitian berlangsun. Sejak awal kajian, peneliti mencoba menemukan makna dari data yang dikumpulkan. Dari data yang terkumpul diperoleh kesimpulan.

\section{HASIL DAN PEMBAHASAN \\ A. Bentuk Interaksi Sosial Di Pasar Induk Namlea}

Suatu interaksi dapat terjadi apabila ada hubungan sosial yang terjalin dengan baik antar sesama individu maupun masyarakat, dimana kelakuan individu yang satu akan mempengaruhi kelakuan individu yang lain atau sebaliknya sehingga kemungkinan terjadi kerjasama yang baik diantara para pelaku interaksi sosial. Setiap individu pastinya akan melakukan hubungan melalui interaksi dengan orang lain dalam aktivitas kesehariannya. Interaksi tersebut dalam bentuk interaksi sosial, politik maupun ekonomi, dan lain-lain. Interaksi yang sering dilakukan oleh masyarakat salah satunya adalah interaksi pada bidang ekonomi misal di pusat perbelanjaan misalnya pasar.

Pasar ialah tempat pembeli dan penjual bertemu, beberapa barang kebutuhan serta jasa tersedia untuk dijual dan akan terjadi proses pemindahan hak milik. Menjalin relasi dalam suatu bisnis adalah suatu hal yang wajar dilakukan oleh setiap individu. Pertemuan penjual dan pembeli dipasar akan memungkinkan terjadinya interaksi sosial. Dalam proses transaksi jual beli di pasar yang dilakukan oleh masyarakat akan menimbulkan hubungan sosial yang dipengaruhi oleh konteks sosial budaya yang berkembang dalam wilayah tersebut.

Interaksi sosial antar pedagang sayur di pasar induk Namlea, dapat terlihat ketika sedang tidak ada pelanggan. Hal ini dijumpai di pusat perbelanjaan yang berada di pasar induk Namlea Kabupaten Buru, proses interaksi yang terjadi di pasar induk Namlea terbagi ke dalam dua kategori, yaitu interaksi sosial asosiatif dan disosiatif.

\section{Interaksi Sosial Asosiatif}




\section{a. Kerja Sama}

Kerja sama atau cooperation juga dikenal sebagai perwujudan minat dan perhatian seorang individu kepada individu yang lain untuk mekerja bersama-sama dengan memiliki kesepahaman yang sama, meskipun kerjasama tersebut motifnya lebih dominan mengarah kepada kepentingan pribadi yang diawali dengan proses interaksi.

Pedagang sayur di pasar Induk Namlea membangun kerjasama melalui bentuk interaksi sosial. Awal terbentuknya pasar ini juga merupakan hasil dari kerjasama antara pedagang, masyarakat sekitar dan pemerintah. Dari hal ini dapat disimpulkan bahwa kerjasama adalah bentuk interaksi sosial yang dimana interaksi tersebut terjadi anatara individu dengan individu, individu dengan kelompok, maupun kelompok dengan kelompok.

Beberapa bentuk kerja sama yang terjadi dipasar induk Namlea, yaitu: Pertama, Pedagang dengan pedagang. Pasar merupakan tempat pertemuan pedagang dan pembeli, beberapa barang dan jasa tersedia dan akan terjadi pemindahan hak milik, pertemuan ini akan memungkinkan terjadinya interaksi sosial. Dalam proses transaksi antara pedagang dengan pembeli, akan memberikan peluang untuk melakukan hubungan sosial sesuai konteks budaya yang berkembang dari masing-masing individu. Kerjasama antar pedagang ini merupakan jenis interaksi yang tidak terlalu nampak. Kerjasama ini terbangun, apabila salah satu pedagang memiliki urusan mendadak atau mereka sudah ingin pulang namun masih ada dagangan yang belum laku sehingga dagangan yang belum laku akan dititip ke pedagang lain dan sebagian keuntungan dari barang dagangan yang telah laku akan diberikan juga kepada pedagang yang ditempati menitip.

Kedua, Pedagang dengan pelanggang. Kerja sama antara pedagang dengan pelanggang merupakan jenis interaksi individu dengan individu. Kerjasama ini terjadi untuk menjalin hubungan bisnis yang merupakan kunci bagi setiap pedagang agar barang dangannya cepat laku terjual. Kerjasama ini didasari dengan kepercayaan dan ikatan emosional, setiap pedagang sudah memiliki pelanggang tetap. Pelanggang tetap akan diberikan harga spesial oleh para pedagang, sehingga hal ini yang membuat pelanggang enggan untuk berpaling ke pedagang lain.

Ketiga, Pedagang dengan tukan Ojek. Interaksi ini terjadi ketika para pedagang sayur memiliki pesananan yang ingin diantar ke salah satu rumah pelanggang. Beberapa pedagang sayur lebih memilih menggunakan jasa tukang ojek, karena dianggap lebih cepat dan aman. Jenis kerjasama ini termasuk kerjasama yang paling sering dilakukan oleh para pedagang, hampir di setiap sudut pasar induk Namlea dapat ditemui suatu interaksi antara pedagang sayur dengan tukan ojek, yang apabila ditelusuri dapat diketahui bahwa interaksi yang dilakukan oleh keduanya adalah bentuk interaksi kerjasama. Keempat, Pedagang dengan distributor. Ini merupakan bentuk interaksi kelompok dengan individu, dalam hal ini pedagang bertindak sebagai kelompok dan distributor sebagai individu. Kerjasama ini terjadi ketika para pedagang sayur akan melakukan transaksi barang dagangan yang akan dipasarkan. Di sisi lain tujuan kerjasama ini adalah agar barang dagangan selalu ada atau tersedia untuk siap dijual setiap hari. Diawal interaksinya para pedagang memilih untuk melakukan kerjasama terlebih dahulu dengan distributor agar harga sayuran yang diambilnya tidak terlalu mahal.

\section{b. Asimilasi}

Setiap kelompok masyarakat yang telah berasimilasi, maka akan merasakan adanya suatu kebudayaan tunggal yang dirasakan sebagai milik bersama karena adanya pembauran budaya. Asimilasi akan mengikis budaya asli dan mengarah kepada lenyapnya perbedaan. Beberapa perbedaan ayang ada akan tergantikan dengan kesamaan paham budaya, sehingga karena itu pula akan digantikan oleh kesatuan pikiran, perilaku dan juga tindakan.

Proses asimilasi ini juga terjadi di pasar induk Namlea, yang dapat dilihat di setiap aktivitas keseharian pedagang saat berinteraksi dengan pembeli ketika sedang melakukan transaksi jual beli. Mayoritas pedagang sayur memahami bahasa Buru, para pedagang sayur berasal dari berbagai daerah, juga budaya yang berbeda-beda. Sehingga proses asimilasi sering terjadi, tetapi sebagian pedagang masih tetap 
memegan teguh budayanya dengan tidak bermaksud menimbulkan diskriminasi dalam lingkungannya.

\section{c. Akomodasi}

Bentuk interaksi akomodasi yang terjadi di pasar induk Namlea, adalah interaksi yang sering terjadi di waktu-waktu tertentu yang dilakukan oleh para pedagang dengan pedagang lainnya. Bentuk interaksi ini terjadi ketika terjadi konflik antar para pedagang, konflik antar pedagang sering terjadi ketika terjadi perebutan lapak antara pedagang yang satu dengan pedagang lainnya.

Perebutan lapak dagangan biasanya menjadi akar permasalahan dan menimbulkan cek-cok mulut antar pedagang, sehingga dalam permasalahan ini sering kali kepala pasar induk Namlea yang turun tangan menjadi penengah untuk meredakan situasi dan memberi peringatan kepada kedua belah pihak untuk tidak mengulangi masalah yang sama.

\section{Interaksi Disosiatif}

Beberapa bentuk interaksi disosiatif, terjadi dalam bentuk persaingan dan kontravensi. Persaingan adalah salah satu model interaksi disosiatif yang cukup sederhana. Proses ini merupakan proses sosial yang di dalamnya terkandung perjuangan untuk memperebutkan atau mempertahankan targettarget terencana yang bersifat terbatas guna mempertahankan kebutuhan ekonomi. Pasar pada dasarnya selalu menjadi wadah untuk bersaing. Dengan adanya aktivitas berebut perhatian pelanggang yang dilakukan oleh pedagang, maka hal ini bukan lagi menjadi hal yang baru dalam proses jual beli di pasar, aktivitas seperti itu juga dapat ditemukan di pasar induk Namlea. Tipe persaingan yang terjadi di pasar Namlea adalah tipe persaingan yang bersifat pribadi, yaitu persaingan yang dilakukan langsung oleh para pedagang dalam melakukan penawaran dagangan kepada pembeli dengan melakukan berbagai model interaksi.

Proses persaingan terjadi apabila beberapa individu atau kelompok berusaha saling mencari keuntungan dalam setiap aktivitasnya, hal ini bisa terjadi di beberapa bidang-bidang tertentu termasuk pada bidang ekonomi. Dengan adanya keterbatasan pengadaan jumlah benda yang menjadi pemuas kebutuhan masyarakat, sementara kebutuhan masyarakat tinggi. Maka hal demikianlah yang menjadi faktor pemicu munculnya persaingan dalam bidang ekonomi. Model persaingan yang terjadi di pasar Namlea pada bidang ekonomi berfokus pada perebutan pelanggang, sedangkan perebutan lokasi penjualan dan sumber bahan baku adalah bagian dari model persaingan produksi barang dan jasa.

Persaingan yang terjadi di pasar Namlea yang dilakukan oleh para pedagang adalah persaingan yang bersifat individu. Mereka berlomba-lomba dan melakukan berbagai cara untuk merebut perhatian para pelanggang yang berkunjung dan melintas di pintu masuk pasar Namlea.

Sedangkan, kontravensi merupakan sikap metal tersembunyi terhadap orang lain atau terhadap unsur-unsur kebudayaan pada suatu golongan tertentu, dalam artian kontravensi berada diantara persaingan dengan konflik. Kontranvensi terjadi ditandai dengan adanya ketidakpastian terhadap diri sendiri atau perasaan keragu-raguan terhadap sesuatu yang telah direncanakan. Kontravensi yang terjadi di pasar Namlea merupakan bentuk interaksi yang terjadi antara individu dengan individu. Banyak para pedagang takut mengalami kerugian apabila barang dagangan mereka tidak terjual, hal ini memicu keragu-raguan terhadap diri sendiri namun persepsi pedagang terhadap pedagang yang lain masih bersifat tersembunyi.

\section{B. Faktor Terjadinya Interaksi Sosial}

Setiap bentuk interaksi sosial yang terjadi di lingkungan masyarakat, terkhusus bentuk interaksi yang terjadi di pasar Induk Namlea yang terletak di Kabupaten Buru dipengaruhi oleh beberapa faktor, yaitu:

Pertama, kerja sama. Hubungan kerja sama terbangun dengan adanya tujuan yang sama terhadap sesama pedagang, beberapa tujuan yang sama yang dimiliki oleh sesama pedagang adalah sama-sama mencari keuntungan dari hasil jualan. Dengan tujuan yang sama inilah mengharuskan para pedagang untuk memilih melakukan hubungan kerja sama. Kerja sama sama seperti ini terlihat saat waktu subuh, ketika pasar masih sunyi dari pengunjung. Sebelum melakukan kerja sama 
dengan pemasok, maka lebih awal para pedagang telah membangun kerja sama dengan para pedagang yang lain untuk sama-sama menawarkan harga yang dianggap bisa meraih untung yang maksimal dari pemasok. Karena akan terjadi perbedaan harga yang signifikan apabila tidak ada penawaran harga yang sama dari para pedagang. Hal lain yang menjadi faktor terbangunnya kerja sama adalah kedekatan fisik terhadap sesama pedagang, dikarenakan apabila ada salah satu pedagang yang ingin memindahkan barang dagangan atau kepentingan mendesak, maka mereka kembali membangun kerja sama dengan menitip barang dagangan kepada pedagang lain.

Kedua, asimilasi dan akomodasi. Beberapa hal yang menjadi penyebab terjadinya asimilasi adalah dengan adanya perbedaan kebudayaan terhadap sesama pedagang, walaupun pasar ini terletak di Desa Namlea Kabupaten buru yang mayoritas berasal dari Buru namun para pedagang di pasar tersebut juga terdapat beberapa suku yang berasal dari wilayah Indonesia. Dengan adanya beberapa pedagang yang berasal dari berbagai daerah, dan pelanggang mayoritas berasal dari Buru. Maka hal ini membuat para pedagang untuk memahami bahasa Buru, agar mereka bisa melakukan komunikasi yang baik dengan pelanggang. Sehingga beberapa pedagang yang berasal dari suku lain lebih memilih menggunakan bahasa buru dalam menawarkan dan melakukan interaksi dengan alasan keakraban dengan pelanggang. Meskipun di pasar Namlea banyak para pedagang yang berasal dari berbagai daerah, namun tidak pernah ditemui diskriminasi antar budaya, karena mereka memiliki sifat toleransi yang baik. Sedangkan akomodasi terjadi apabila ada konflik antar pedagang, konflik inilah yang menjadi faktor utama terjadinya akomodasi di pasar Namlea. Perbedaan pendapat atau ketidak sepahaman dari beberapa pihak yang bersengketa mengharuskan dilakukannya akomodasi yang dilakukan oleh kepala pasar sebagai penengah.

Ketiga, persaingan. Terjadinya proses persaingan pedagang sayur di pasar Namlea depengaruhi dengan banyaknya jumlah pedagang yang terus bertambah. Pasar induk
Namlea merupakan pusat perdagangan yang berada di Kabupaten Buru, sehingga tidak diragukan jika banyaknya jumlah pedagang yang menjadi faktor utama terjadinya persaingan antar pedagang di pasar Namlea. Sedangkan yang kedua adalah kurangnya jumlah pelanggang. Keempat, kontravensi. Kontravensi terjadi karena pribadi antar pedagang berbeda antara yang satu dengan lainnya, serta kepribadian pelanggang yang juga berbeda-beda. Hal ini, disebabkan karena beberapa pedagang dan pelanggang berasal dari berbagai daerah yang masih dipengaruhi oleh adat istiadat serta budayanya.

Keempat, konflik. Cek-cok yang dilakukan antar pedagang, menjadi salah satu penyebab terjadinya konflik. Cek-cok sering terjadi karena seringnya ada masalah tentang uang arisan yang dilakukan oleh para pedagang, yang terkadang berakhir dengan kekerasan fisik. Sarana dan prasarana yang terkadang tidak memadai, menjadi faktor kedua terjadinya konflik. Tidak terpenuhinya kebutuhan sarana dan prasarana, sangat berpengaruh terhadap kepuasan pedagang dan pelanggang di pasar. Karena hal itu sangan merugikan keduanya, apabila sarana dan prasarana tidak memadai, dan bisa memicu terjadinya konflik.

\section{KESIMPULAN}

Bentuk interaksi sosial yang dilakukan oleh pedagang sayur di pasar Namlea Kabupaten Buru, merupakan bentuk interaksi yang terjadi secara individu dengan individu, kelompok dengan kelompok maupun individu dengan kelompok. Bentuk interaksi ini terjadi di waktu-waktu tertentu, dan terbagi kedalam dua bentuk yaitu interaksi sosial asosiatif dan disosiatif. Interaksi sosial asosiatif terjadi dalam bentuk kerja sama, asimilasi dan akomodasi.

Beberapa faktor yang mempengaruhi terjadinya bentuk interaksi sosial, yaitu: Pertama, kerja sama. Kerja sama ini terbangun dengan adanya tujuan yang sama, kedekatan fisik antar pedagang dan tujuan yang lain selain berdagang. Kedua, asimilasi dan akomodasi. Asimilasi terjadi karena adanya perbedaan budaya antar pedagang sayur, kepentingan komunikasi dan sikap saling menghargai antar pedagang. Sedangkan akomodasi terjadi ketika 
ada pertentangan atau cek cok antar pedagang. Ketiga, persaingan. Hal ini, terus terjadi karena jumlah pelanggang yang kurang sedangkan jumlah pedagang sayur terus bertambah. Keempat, konflik. Seringnya terjadi konflik disebabkan oleh kepribadian pedagang yang berbeda-beda, rasio jumlah pedagang tidak seimbang dengan jumlah pelanggang, struktur penempatan setiap pedagang dan denah bangunan pasar yang masih dianggap belum efektif.

\section{SARAN}

Masih perlu melakukan penelitian lain berkaitan dengan masalah yang diangkat pada penelitian ini tentang beberapa bentuk interaksi sosial pedagang sayur dan faktor yang mempengaruhi. Hal ini dilakukan untuk melakukan perbandingan dan mempermuda dalam mengkaji masyarakat mengenai interaksi sosial yang terjadi di lingkungan masyarakat.

\section{UCAPAN TERIMA KASIH}

Ucapan terima kasih kepada Allah SWT, yang telah memberikan saya kesehatan dalam menyelesaikan penelitian ini. Serta ucapan terima kasih kepada pihak Direktorat Riset dan Pengabdian Masyarakat Direktorat Jenderal Riset dan Pengembangan Kementerian Riset, Teknologi, dan Pendidikan Tinggi (RISTEKDIKTI) yang telah memberikan bantuan dana.

\section{DAFTAR PUSTAKA}

Arianty, N. (2014). Analisis perbedaan pasar modern dan pasar tradisional ditinjau dari strategi tata letak (lay out) dan kualitas pelayanan untuk meningkatkan posisi tawar pasar tradisional. Jurnal Ilmiah Manajemen dan Bisnis, 13(1).

M. Fadhil Nurdin. (1990). Pengantar Studi Kesejahteraan Sosial, Bandung: Angkasa, Hal. 9.

Muslim, A. (2013). Interaksi sosial dalam masyarakat multietnis. Jurnal Diskursus Islam, 1(3), 483-494.

Nuraini, N., Riadi, A., Umanailo, M. C. B., Rusdi, M., Badu, T. K., Suryani, S., ... \& Hentihu, V. R. (2019). Political Policy for the development of
Education. Int. J. Sci. Technol. Res, 8(10).

RUSDI, M., \& RUSDI, M. (2017). Dinamika Sosial Masyarakat Di Sekiat Bukit Karampuang Desa Barugae Kecamatan Bulukumpa Kabupaten Bulukumba (Doctoral dissertation, Doctoral dissertation, Pascasarjana).

Rusdi, M., Wabula, A. L., Goa, I., \& Ismail, I. (2020). Solidaritas Sosial Masyarakat Petani Di Desa Wanareja Kabupaten Buru. Jurnal Ilmiah Mandala Education, 6(2).

Saptono.(2006). "Sosiologi.". Phibeta: Jakarta, Hal. 72

Soerjono Soekanto.(1990). "Sosiologi Suatu Pengantar". Rajawali Pers: Jakarta, Hal. 54

Soetomo. (2008). Strategi-Strategi

Pembangunan Masyarakat

(Yogyakarta: Pustaka Pelajar.

Triwik Alfia Ningrum dan Muhammad Turhan Yani. (2013) "Pola Interaksi Sosial Antar Pedagang di Wilayah Ampel Surabaya", Jurnal. Surabaya: Universitas Negeri Surabaya Fakultas Ilmu Sosial, Hal. 498

Wabula, A. L., Umanailo, M. C. B., Kurniawan, R., Rusdi, M., \& Nuthihar, R. (2019). GERAKAN BUPOLO MAGHRIB MENGAJI SEBAGAI MEDIA PRURALISME. JISPO: Jurnal Ilmu Sosial dan Ilmu Politik, 9(2), 1-18. 